\title{
Use of Electronic Resources by M.Sc. Chemistry Students at Arts Science and Commerce College Chopda Dist-Jalgaon
}

\author{
Dr.Paithankar Rajeev, R., Mr.Kamble V.R. \\ SRTM University Nanded, SRTM University Nanded
}

\begin{abstract}
The libraries and information services has been changed due to the development of information and communication technology. Electronics resources role is very important as information repositories are use of information for various purposes like academic, research, teaching and learning process. E-resources gives solutions of the traditional libraries as like all data storage in digital format, users can access library without boundaries through internet so e-resources popularity is very continuously growth in teaching learning process. In the modern era librarian should provide better services to the users for accessing e-resources as like e-books, e-journals, e-databases, e-reports etc. E-resources have been used for capture accurate and current information within second so majority learner use e-resources for their learning process. In the 90 th century internet has emerged as the sources of information for storage and retrieve information. In the past few years online information has been continuously increased as like e-journals, e-books, e-databases etc. The emergence of information communication technology traditional library system transfer to digital library system. In the current era majority learning materials are available in electronic formats because theses materials are very useful for students, researcher and other academic staff.
\end{abstract}

\section{INTRODUCTION}

Objectives of the study-

1. To study the library users need and their expectation about electronic resources.

2. To find out users opinion about internet as information sources in modern era.

3. To find out students opinion about effectiveness of e-mail services providers.

4. To find out what is the reason of using internet and e-resources among M.Sc. students.

5. To discuss which problems are arises while using internet and e-resources.

\section{Selection of problems-}

Mahatma Gandhi Shikshan Mandals has run various branches as like, poly., Pharmacy, Nursing, and primary to higher education but researcher select only M.Sc. Chemistry students for writing paper on the topic of " Use of electronic resources by M.Sc. Chemistry students at Arts Science and Commerce College Chopda dist-Jalgaon"

\section{METHODOLOGY}

Survey method used for collection of data from M.Sc. students at Arts Science and Commerce College Chopda Dist-Jalgaon. Questionnaire methods used for collection of data. In this study design questionnaire and 25 distributed to M.Sc. Chemistry students both part I and II after collection the filling questionnaire. Data analysis method has been used tabulation, codification and use measurements of central tendencies.

\section{About the college-}

The college offers education with 24 subjects at the general level and 12 subjects at the special level. There are 10 Post-Graduate departments being run by the college and 05 vocational courses are taken care of too. The teaching staff is fully equipped with the necessary training, qualifications and research attitudes as kept up in the modern times. 10 of the teachers have completed Ph.D., 15 of them have completed M.Phil. While 20 of them are busy with the research.

Table No.1 Level of knowledge about computer and internet access

\begin{tabular}{|l|l|l|l|}
\hline Sr.No. & $\begin{array}{l}\text { Level of } \\
\text { Knowledge }\end{array}$ & Frequency & Percentage \\
\hline 1. & Good & 22 & 88 \\
\hline 2. & Moderate & 02 & 08 \\
\hline 3. & Fair & 01 & 04 \\
\hline 4. & Poor & 00 & 00 \\
\hline Total & & 25 & 100 \\
\hline
\end{tabular}

Table No.1 show that $88 \%$ students level of knowledge about computer and internet is good because of majority students use computer and internet every day for learning process. $08 \%$ students are moderate about knowledge of 
computer and internet. 04\% students are fair about computer and internet and poor knowledge students are $00 \%$.

Table No.2 Students response about internet as a information sources

\begin{tabular}{|l|l|l|l|l|l|}
\hline $\begin{array}{l}\text { Sr. } \\
\text { no. }\end{array}$ & $\begin{array}{l}\text { Features of internet } \\
\text { as information sorces }\end{array}$ & $\begin{array}{l}\text { Strongly } \\
\text { Agree }\end{array}$ & Agree & Disagree & $\begin{array}{l}\text { Strongly } \\
\text { Disagree }\end{array}$ \\
\hline 1 & Easy to access & 18 & 02 & 03 & 02 \\
\hline 2 & $\begin{array}{l}\text { High speed of } \\
\text { searching } \\
\text { information }\end{array}$ & 16 & 04 & 02 & 01 \\
\hline 3 & $\begin{array}{l}\text { Usefulness for } \\
\text { teaching }\end{array}$ & 20 & 03 & 02 & 00 \\
\hline 4 & Related information & 13 & 06 & 04 & 02 \\
\hline 5 & Huge information & 17 & 03 & 03 & 02 \\
\hline 6 & $\begin{array}{l}\text { Save the time an } \\
\text { Money }\end{array}$ & 22 & 02 & 01 & 00 \\
\hline 7 & Flexibility & 21 & 03 & 01 & 00 \\
\hline
\end{tabular}

Table No. Table No.2 show that $72 \%$ students opinion are strongly agree about internet as a powerful information sources and easy to access access and 08of information. 08\% students are agree about internet is very easy to access, $12 \%$ students are disagree about internet is a easy $\%$ students strongly disagree about easy to access. $64 \%$ students are strongly agree while high speed of internet for searching information and $16 \%$ agree, $08 \%$ disagree and $04 \%$ students are disagree about internet speed. 80\%students strongly agree about usefulness of internet, $12 \%$ agree and $04 \%$ disagree about usefulness of internet. 52\% students are strongly agree about internet provide related information to the students, 24\% students are agree, $16 \%$ disagree and $08 \%$ students are strongly disagree about related information. $68 \%$ students are strongly agree about huge information, $12 \%$ agree, $12 \%$ disagree and $08 \%$ students strongly disagree about huge information.88\% students strongly agree about through internet save the time and money, $08 \%$ agree and $04 \%$ students strongly disagree about save the time and money. $84 \%$ students strongly agree flexibility of internet, $12 \%$ students agree and $04 \%$ students disagree about flexibility of internet and e-resources.

Table No.3 Effectiveness of e-mail providers

\begin{tabular}{|l|l|l|l|l|l|l|}
\hline $\begin{array}{c}\text { Sr } \\
\text { no. }\end{array}$ & E-mail providers & $\begin{array}{c}\text { Very } \\
\text { efficient }\end{array}$ & $\begin{array}{c}\text { effic } \\
\text { ient }\end{array}$ & $\begin{array}{c}\text { In } \\
\text { efficient }\end{array}$ & $\begin{array}{c}\text { Very } \\
\text { inefficient }\end{array}$ & $\begin{array}{c}\text { I don't } \\
\text { know }\end{array}$ \\
\hline 1 & www.yahoo.com & 02 & 00 & 00 & 00 & 00 \\
\hline 2 & www.gmail.com & 20 & 02 & 01 & 02 & 00 \\
\hline 3 & www.rediffmail.com & 22 & 02 & 01 & 00 & 00 \\
\hline 4 & www.hotmail.com & & & & 02 & 23 \\
\hline 5 & www.sancharnet.in & 01 & 00 & 00 & 00 & 24 \\
\hline 6 & www.indiatimesmail & 01 & 00 & 00 & 00 & 24 \\
\hline
\end{tabular}

Table No.3 show that $08 \%$ students says that yahoo.com e-mail services are very efficient, $80 \%$ students about www.gmail.com services is very efficient, $08 \%$ students efficient and 04\% students in efficient. $88 \%$ students says that www.rediffmail.com e-mail providers service are very efficient, 08\% students efficient, 04\% students in efficient services.08\% students says that www.hotmail.com e-mail service providers are very inefficient and $92 \%$ students says that I don't know this e-mail providers. 04\% students opinion about search.net services are very efficient and $96 \%$ students says that I don't know about this e-mail providers. Only $04 \%$ students says that www.indiatimesmail services are very efficient and $96 \%$ students don't know about this services. Table No.4 Spending time for accessing internet

1. Less than 2 hours $-02=08 \%$

2. 3 to 6 hours $-16=64 \%$

3. 7 to 10 hours $-07=28 \%$

Table No.4 indicate that only $08 \%$ students says that we only maximum 02 hours spend on internet for accessing electronic resources for learning purpose, $64 \%$ students use of internet about 3 to 06 hours for learning process, $28 \%$ students says that we use internet for accessing electronic resources about 07 to 10 hours.

Table No.05 Problems faced by students while using e-resources

\begin{tabular}{|l|l|l|l|l|l|l|}
\hline $\begin{array}{l}\text { Sr. } \\
\text { No }\end{array}$ & Problems & $\begin{array}{l}\text { Very } \\
\text { often }\end{array}$ & Often & $\begin{array}{l}\text { Not } \\
\text { very } \\
\text { often }\end{array}$ & $\begin{array}{l}\text { Not } \\
\text { at all }\end{array}$ & Never \\
\hline 1 & Finding & 06 & 09 & 05 & 00 & 06 \\
\hline 2 & Download speed & 10 & 02 & 01 & 03 & 09 \\
\hline 3 & Time problem & 02 & 02 & 01 & 10 & 10 \\
\hline 4 & $\begin{array}{l}\text { Do not proper } \\
\text { information }\end{array}$ & 03 & 02 & 01 & 09 & 10 \\
\hline 5 & Lack of searching & 02 & 02 & 01 & 01 & 19 \\
\hline 6 & Electricity problem & 01 & 00 & 00 & 00 & 24 \\
\hline 7 & Technical problem & 01 & 02 & 03 & 09 & 10 \\
\hline
\end{tabular}

$4 \%$ students says that finding of information problems are arise very often, $36 \%$ students often, $20 \%$ students not very often and $24 \%$ students says than finding problems are never coming while using internet. $40 \%$ students speed problems are coming very often, $08 \%$ students often, $04 \%$ students not very often and $36 \%$ students never arise speed problems.

\section{CONCLUSION}

Majority students of M.Sc. Chemistry students their good knowledge about internet and $72 \%$ students opinion about internet is easy to access of information is strongly agree. Majority students are aware about various e-mail services 
providers specially gmail.com and rediffmail.com services are company use for their transfer of information and other purpose. 64\% students use of internet and electronic resources about 03 to 06 hours in every day for getting information.

\section{REFERENCES}

[1] Lakshmi. (2010). Recent trends in library science. (1 ed.). New Delhi: Sarup Book Publishers Pvt.Ltd.

[2] Jena, S. (2013). Ict for library professionals. New Delhi: SSDN Publishers \&Distributors.

[3] Sethunath. (2012). Digital library systems. New Delhi: CRESCENT Pub.Corporation.

[4] Dhar, M. (2010). Research and technical libraries. New Delhi: Ess Ess Publication.

[5] Gupta. (2005). Teaching and research aptitude. New Delhi: Pratiyogita sahitya siries. 